Some Pros and Cons of Multistakeholder Initiatives

\section{Can Stakeholders do the Trick?}

\section{Neve Formen der Unternehmenssteverung, oft Multistakeholder Initiativen ge- nannt, sind in den letzten Jahren entwickelt worden, um die Leistungen von großen Firmen in den Bereichen Soziales, Umwelt und Menschenrechte zu ver- bessern. Multistakeholder Ansätze sind eine Reaktion auf die Probleme und Schwächen von Selbstverpflichtungen und Unternehmensstandards, die mit ei- ner Reihe von Verfahren wie Zertifizierung und verbesserter Überwachung op- timiert werden sollen. Der Artikel gibt einen Überblick über die gängigsten Me- thoden im Feld und diskutiert deren Vor- und Nachteile.}

I Von Peter Utting $\mathrm{n}$ recent decades there has been a considerable rethink concerning the ways and means of improving the social and environmental performance of transnational corporations (TNCs) (1). In response to criticism of company codes of conduct and other recent self-regulatory initiatives, attention has been directed at new forms of ,,coregulation" or "multistakeholder initiatives" (MSIs). In MSIs business is regulated by institutions and organizations involving a combination of actors associated with business, NGOs, trade unions, governmental and multilateral organizations. Such schemes encourage companies to adhere to sets of principles, guidelines or codes that address economic, social and environmental dimensions of corporate responsibility. They also promote various forms of monitoring, social and environmental reporting and auditing, certification of good practice, stakeholder dialogues and public-private partnerships.

Examples of MSIs include AA1000, the Clean Clothes Campaign (CCC), the Ethical Trading Initiative (ETI), the Fair Labor Association (FLA), the Forest Stewardship Council (FSC), the Global Alliance for Workers and Communities, the United Nations Global Compact, Global Framework Agreements between international trade union organizations and TNCs, the Global Reporting Initiative (GRI), ISO 14001, the Marine Stewardship Council (MSC), SA8000, Worldwide Responsible Apparel Production (WRAP) and the Worker Rights Consortium (WRC).

Although many such schemes are still in their infancy, this paper attempts to identify some of the strengths and weaknesses, and considers whether MSIs are likely to constitute an effective model of global corporate regulation.

\section{Scale and Quality}

Despite the increasing number of MSIs, the volume of companies involved remains relatively small. This is partly a function of their recent origin and the vast number of TNCs (65.000), affiliates (850.000) and millions of suppliers worldwide (2). Certification schemes, such as ISO 14001 and the FSC, which have a slightly longer history, suggest some scope for expansion but even these initiatives involve only a small proportion of companies.

Many schemes have spent their early years absorbed in a pilot phase involving very few companies. Scaling up these initiatives to embrace large numbers of companies and sectors confronts major obstacles. While social pressures associated with civil society and consumer activism, and economic pressures and opportunities associated with access to export markets have stimulated interest in certain MSIs, most firms remain fairly immune to the carrots and sticks driving participation in MSIs. The companies involved are often the high profile brand name companies, facing risks associated with their social and environmental performance or reputation, or these and others interested in facilitating access to northern export markets.

The scaling up of MSIs is heavily constrained by their cost and complexity. A primary objective of MSIs has been to improve the quality of standardsetting, implementation of principles and norms, reporting, auditing, monitoring and verification procedures, which were often weak under corporate self-regulation. MSIs have, indeed, addressed some of the major gaps in self-regulatory codes, notably those related to labour rights, the responsibilities of suppliers and provisions for indepen- dent monitoring. In relation to labour standards, SA8000, the Ethical Trading Initiative, the Clean Clothes Campaign, the Fair Labor Association, the Global Framework Agreements, the Global Compact and the Worker Rights Consortium all stress the importance of the ILO Core Labour Conventions related to prohibitions on child labour, discrimination in the workplace and the use of forced labour, as well as the right to collective bargaining and freedom of association. Apart from the Global Compact, these initiatives also contain explicit provisions dealing with minimum wages.

Another potential advantage of MSIs is their attempt to impose some degree of harmonization and standardization on the broad number and variety of codes of conduct. In some sectors, however, MSIs are also proliferating with several competing base codes and independent monitoring systems.

\section{Different Approaches}

There are considerable differences in the approaches adopted by MSIs to improve corporate social and environmental policy and performance. Some such as IS014001, AA1000, and ETI, emphasize certification and/or monitoring of policies and management systems. The FSC, SA8000 and FLA are concerned not only with ,process“ but also certifying actual performance and impacts. Others, such as the Global Reporting Initiative and the Global Compact, focus on voluntary reporting. The WRC, Global Framework Agreements and Clean Clothes Campaign promote not only external or independent monitoring but also complaints procedures.

MSIs are often faced with a dilemma when it comes to the methods they emphasize to promote changes in management systems. An approach that emphasizes innovation and the promotion of new values and competencies through dialogue and social learning can result in ,over-flexibility“, which can ultimately undermine the credibility of the initiative. An approach that emphasizes the development of rules-based systems and ,codification" can result in a simpler checklist approach that may be easier to apply but may undermine the effective assessment of workplace conditions and the possibility of inducing significant changes in corporate culture (3).

There appears to be a significant trade-off between "quality" and ,scale“. The CCC and WRC initiatives, for example, are employing comprehensive monitoring and verification methods but engage with 
only a handful of companies. In contrast, certain certification schemes like ISO 14001, SA8000 and the FLA involve many more companies but rely heavily on large accounting and auditing firms. Their methods have been questioned for their superficiality and inability to assess accurately and objectively workplace conditions, labour and community relations, and environmental impacts (4). Accessing and obtaining meaningful information can be extremely difficult given the expertise required, the reluctance of both workers and management to communicate openly and honestly, and the typically short timeframe of any monitoring or reporting exercise (5).

\section{- Credibility and Participation}

Ongoing credibility problems of several MSIs relate to weaknesses in monitoring and other procedures; imbalances in stakeholder representation that affect design, implementation and ,social control"; and the legitimacy of certain stakeholders.

By their very nature, MSIs attempt to bring into decision-making processes a broader range of actors but some initiatives have ignored or marginalized workers, trade unions, local-level monitoring and verification organizations in developing countries, and „Southern“ actors more generally.

Southern workers are often seen as ,victims" that need help rather than as actual or potential agents of change. Concerns have arisen as to whether the types of standards promoted by MSIs really address the priority concerns and problems of Southern workers. More thought also needs to be given to the cost and protectionist implications of some CSR initiatives, and their impact on small and medium-sized firms in developing countries. This includes the crucial issues of ,shared responsibility“, i.e. sharing costs with suppliers, and how to minimize „cut and run“ tactics, i.e. the practice of severing abruptly contracts with suppliers that fail to meet agreed standards.

The degree of independence from business interests can sometimes be a pointer as to how rigorous an initiative is in terms of the standards adopted and the quality of monitoring, verification and disclosure. Criticisms of schemes like ISO 14001, the Global Compact, MSC and WRAP sometimes establish a connection between what are regarded as fairly weak standards, monitoring or disclosure provisions and the fact that such initiatives have been strongly influenced by business interests with relatively weak civil society participation.
The issue of credibility of MSIs also relates to the role of NGOs in systems of global governance. Unlike trade unions, which have a membership base and electoral procedures, NGOs lack the legitimacy that derives from such arrangements and are largely unaccountable to certain stakeholders. This raises the question of whether such organizations should assume a leading role in constituting new systems of global corporate regulation (6).

\section{- Complaints and Corporate Accountability}

Given the complexity of some types of MSIs and the difficulty of significantly scaling them up, other alternatives need to be considered. Particularly important are procedures and institutions to detect breaches of agreed standards. Such complaints-based systems of regulation or complaints procedures can assume numerous institutional forms involving legal/judicial systems, collective bargaining, ,ombudsman“ type arrangements or „naming and shaming“ publicity. While some MSIs include complaints procedures such aspects have often remained marginal.

Recently, new forms of co-regulation, which focus on mechanisms for ensuring ,,corporate accountability" have been put forward by civil society and

Schlüssel-
technologien
für Nachbaltigkeit

und

Partizipation
und Unternebmen

sind die Themen
der Informationsdienste

\section{Ökologisches Wirtschaften $6 / 03$ und $1 / 04$}

Wenn Sie potenzielle Beiträge haben, wenden Sie sich bitte an die Redaktion. international organizations. Such proposals emphasize not only complaints procedures but also the role of international soft-law and inter-governmental organizations in corporate regulation. They also direct attention to issues of corporate power (7). Rather than simply urging companies to improve their performance, such proposals suggest that companies must be held to account for their actions and impacts. This is likely to depend on a range of participatory and legal mechanisms that go beyond conventional voluntary initiatives.

\section{References}

(1) This paper is a summary of Utting, Peter: „Regulating Business via Multistakeholder Initiatives. A Preliminary Assessment". In: NGLS/UNRISD, Voluntary Approaches to Corporate Responsibility: Readings and a Resource Guide, NGLS/UNRISD, Geneva 2002 (also available on www.unrisd.org).

(2) UNCTAD: World Investment Report: Transnational Corporations and Export Competitiveness, UNCTAD, New York and Geneva 2002.

(3) Zadek, Simon: The Civil Corporation: The New Economy of Corporate Citizenship , Earthscan, London 2001.

(4) O'Rourke, Dara: Monitoring the Monitors: A Critique of PricewaterhouseCoopers(PwC) Labor Monitoring. (Accessed at web.mit.edu/dorourke/www/index.html)

(5) Ascoly, N., Oldenziel, J. and Zeldenrust I: Overview of Recent Developments on Monitoring and Verification in the Garment and Sportswear Industry in Europe, SOMO, Amsterdam.

(6) Ottaway, Marina: „Corporatism Goes Global: International Organizations, NGO Networks and Transational Business". In: Global Governance, Vol. 7, №. 3, September 2001 (Accessed at www.ceip.org).

(7) Bendell, Jem: Barricades and Boardrooms: The Challenge of Corporate Power to World Development (provisional title), mimeo, UNRISD, Geneva 2003.

\section{Der Autor}

Peter Utting ist Forschungskoordinator am United Nations Research Institute for Social Development (UNRISD), wo er ein internationales Programm zu Corporate Social Responsibility und Entwicklung leitet. Kontakt: UNRISD, Palais des Nations, 1211 Genf 10, Schweiz, Tel. 0041-22-9172951, E-Mail: utting@unrisd.org 
(c) 20I0 Authors; licensee IÖW and oekom verlag. This is an article distributed under the terms of the Creative Commons Attribution Non-Commercial No Derivates License (http://creativecommons.org/licenses/by-nc-nd/3.o/), which permits unrestricted use, distribution, and reproduction in any medium, provided the original work is properly cited. 